\title{
Front Matter: Volume 10499
}

, "Front Matter: Volume 10499," Proc. SPIE 10499, Three-Dimensional and Multidimensional Microscopy: Image Acquisition and Processing XXV, 1049901 (20 March 2018); doi: 10.1117/12.2323022

SPIE. Event: SPIE BiOS, 2018, San Francisco, California, United States 


\title{
PROGRESS IN BIOMEDICAL OPTICS AND IMAGING

\section{Three-Dimensional and Multidimensional Microscopy: Image Acquisition and Processing $X X V$}

\author{
Thomas G. Brown \\ Carol J. Cogswell \\ Tony Wilson \\ Editors
}

29-31 January 2018

San Francisco, California, United States

Sponsored and Published by

SPIE 
The papers in this volume were part of the technical conference cited on the cover and title page. Papers were selected and subject to review by the editors and conference program committee. Some conference presentations may not be available for publication. Additional papers and presentation recordings may be available online in the SPIE Digital Library at SPIEDigitalLibrary.org.

The papers reflect the work and thoughts of the authors and are published herein as submitted. The publisher is not responsible for the validity of the information or for any outcomes resulting from reliance thereon.

Please use the following format to cite material from these proceedings:

Author(s), "Title of Paper," in Three-Dimensional and Multidimensional Microscopy: Image Acquisition and Processing XXV, edited by Thomas G. Brown, Carol J. Cogswell, Tony Wilson, Proceedings of SPIE Vol. 10499 (SPIE, Bellingham, WA, 2018) Seven-digit Article CID Number.

ISSN: 1605-7422

ISSN: 2410-9045 (electronic)

ISBN: 9781510614833

ISBN: 9781510614840 (electronic)

Published by

SPIE

P.O. Box 10, Bellingham, Washington 98227-0010 USA

Telephone +1 3606763290 (Pacific Time) · Fax +1 3606471445

SPIE.org

Copyright @ 2018 , Society of Photo-Optical Instrumentation Engineers.

Copying of material in this book for internal or personal use, or for the internal or personal use of specific clients, beyond the fair use provisions granted by the U.S. Copyright Law is authorized by SPIE subject to payment of copying fees. The Transactional Reporting Service base fee for this volume is $\$ 18.00$ per article (or portion thereof), which should be paid directly to the Copyright Clearance Center (CCC), 222 Rosewood Drive, Danvers, MA 01923. Payment may also be made electronically through CCC Online at copyright.com. Other copying for republication, resale, advertising or promotion, or any form of systematic or multiple reproduction of any material in this book is prohibited except with permission in writing from the publisher. The CCC fee code is $1605-$ $7422 / 18 / \$ 18.00$

Printed in the United States of America.

Publication of record for individual papers is online in the SPIE Digital Library.

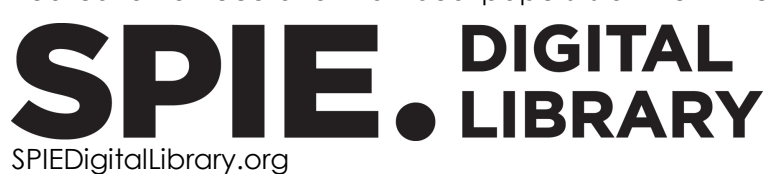

SPIEDigitalLibrary.org

Paper Numbering: Proceedings of SPIE follow an e-First publication model. A unique citation identifier (CID) number is assigned to each article at the time of publication. Utilization of CIDs allows articles to be fully citable as soon as they are published online, and connects the same identifier to all online and print versions of the publication. SPIE uses a seven-digit CID article numbering system structured as follows:

- The first five digits correspond to the SPIE volume number.

- The last two digits indicate publication order within the volume using a Base 36 numbering system employing both numerals and letters. These two-number sets start with 00, 01, 02, 03, $04,05,06,07,08,09,0 A, 0 B \ldots$. 0Z, followed by 10-1Z, 20-2Z, etc. The CID Number appears on each page of the manuscript. 


\title{
Contents
}

\author{
vii Authors \\ ix Conference Committee
}

\section{STRUCTURED ILLUMINATION IN MULTIDIMENSIONAL MICROSCOPY}

1049903 3D structured illumination microscopy using an incoherent illumination system based on a Fresnel biprism [10499-2]

\section{HOLOGRAPHY AND SCATTEROMETRY}

$10499093 \mathrm{D}+$ time acquisitions of 3D cell culture by means of lens-free tomographic microscopy [10499-7]

10499 OC Scatterer density sensitive tomography utilizing light and ultrasound [10499-10]

\section{ALGORITHMS AND IMAGING THEORY}

10499 OE Theory and applications of structured light single pixel imaging [10499-12]

10499 OF Tradeoff between insensitivity to depth-induced spherical aberration and resolution of 3D fluorescence imaging due to the use of wavefront encoding with a radially symmetric phase mask [10499-13]

\section{POLARIZATION AND LIGHT FIELD MICROSCOPY}

10499 OR Snapshot 3D tracking of insulin granules in live cells [10499-17]

\section{OPTICAL SYSTEMS FOR MULTIDIMENSIONAL MICROSCOPY}

10499 oW Fabrication and characterization of novel microsphere-embedded optical devices for enhancing microscopy resolution [10499-22]

\section{NEW METHODS FOR PARTICLE TRACKING}

$104990 Z$ Dual-view inverted selective plane illumination microscopy (diSPIM) with improved background rejection for accurate 3D digital pathology [10499-25]

1049911 Particle tracking and extended object imaging by interferometric super resolution microscopy [10499-27] 
1049913 Investigation of second harmonic generation and multispectral imaging as new contrast mechanisms in scanning laser optical tomography [10499-29]

1049916 Spatiotemporal polarization modulation microscopy with a microretarder array [10499-32]

\section{WAVEFRONT CODING AND POINT SPREAD FUNCTION ENGINEERING}

1049918 Single image structured illumination (SISIM) for in-vivo imaging [10499-34]

$104991 \mathrm{~A}$ Evaluation of the use of wavefront encoding to reduce depth-induced aberration in structured illumination microscopy [10499-36]

\section{MULTIDIMENSIONAL IMAGING OF BIOLOGICAL SYSTEMS}

10499 1C Imaging a seizure model in zebrafish with structured illumination light sheet microscopy [10499-38]

10499 1E 4D blood flow mapping using SPIM-microPIV in the developing zebrafish heart [10499-40]

10499 IF Imaging the developing heart: synchronized time-lapse microscopy during developmental changes [10499-41]

NEW METHODS IN MICROSCOPY

$1049911 \quad$ Low cost light-sheet microscopy for whole brain imaging [10499-44]

POSTER SESSION

10499 1L Hyper-spectrum scanning laser optical tomography [10499-46]

1049910 Estimation of point spread function of an imaging system using a programmable target [10499-49]

10499 1P Sultability of holographic beam scanning in high resolution applications [10499-50]

$104991 Q \quad$ Volumetric bioimaging based on light field microscopy with temporal focusing illumination [10499-51]

10499 IR Hybrid of two-photon microscopy and optical multimodality imaging for multi-scale imaging of small animals [10499-52]

$104991 \mathrm{U}$ Light-sheet enhanced resolution of light field microscopy for rapid imaging of large volumes [10499-55] 
10499 IV Autofocusing in digital holography using deep learning [10499-56]

10499 IW Multiplexing and de-multiplexing with scattering media for large field of view and multispectral imaging [10499-57]

1049912 Preprocessing method to correct illumination pattern in sinusoidal-based structured illumination microscopy [10499-60]

1049920 Correlative FRET: new method improves rigor and reproducibility in determining distances within synaptic nanoscale architecture [10499-61]

1049921 Engineering the on-axis intensity of Bessel beam by a feedback tuning loop [10499-62]

1049923 Round robin test on V-shape bio-imaging transfer standard for determination of the instrument transfer function of 3D optical profilers [10499-64] 
Proc. of SPIE Vol. 10499 1049901-6

Downloaded From: https://www.spiedigitallibrary.org/conference-proceedings-of-spie on 26 Apr 2023 Terms of Use: https://www.spiedigitallibrary.org/terms-of-use 


\title{
Authors
}

Numbers in the index correspond to the last two digits of the seven-digit citation identifier (CID) article numbering system used in Proceedings of SPIE. The first five digits reflect the volume number. Base 36 numbering is employed for the last two digits and indicates the order of articles within the volume. Numbers start with 00, 01, 02, 03, 04, 05, 06, 07, 08, 09, 0A, 0B...0Z, followed by 10-1Z, 20-2Z, etc.

\author{
Allier, Cédric, 09 \\ Antonopoulos, Georgios C., 13 \\ Arbeláez, Pablo, $1 \mathrm{U}$ \\ Artigas, Roger, 23 \\ Ball, Rebecca, 1C \\ Baraban, Scott, $1 \mathrm{C}$ \\ Bartels, Randy A., OE \\ Berdeu, Anthony, 09 \\ Bermudez, Carlos, 23 \\ Bolus, Daniel, $0 Z$ \\ Bordy, Thomas, 09 \\ Borvah, Bosanta R., 10, 1P \\ Brown, J. Quincy, $\mathrm{OZ}$ \\ Buckley, Charlotte, $1 \mathrm{~F}$ \\ Castro, Diego, $1 \mathrm{U}$ \\ Chen, Lingling, $1 \mathrm{~L}$ \\ Chen, Shean-Jen, 1Q \\ Connell, Samuel, 20 \\ Cossairt, Oliver (Ollie), 11 \\ Daddysman, Matthew, OR, 11 \\ Dale, Savannah, 1C \\ Dang, Cuong, IW \\ Darafsheh, Arash, OW \\ Denvir, Martin A., $1 F$ \\ DiMarzio, Charles A., 0C, 18 \\ Ding, Changqin, 16 \\ Doblas, Ana, 03, OF, 1A, 12 \\ Dutta, Ananya, OF \\ Ferrier, Nicola, 11 \\ Forero-Shelton, Manu, $1 \mathrm{U}$ \\ Gdor, Itay, OR, 11 \\ Gidrol, Xavier, 09 \\ Goutam Buddha, S. S., 10, 1P \\ Haeggström, Edward, 23 \\ Haunold, Theresa, OR \\ Heisterkamp, Alexander, 13 \\ Hereld, Mark, OR, 11 \\ Hoffman, Zachary R., 18 \\ Holt, R. Glynn, OC \\ Hsu, Feng-Chun, 1Q \\ $\mathrm{Hu}$, Bihe, $\mathrm{OZ}$ \\ Hu, Xuejuan, $1 \mathrm{~L}$ \\ Huang, Xiang, OR \\ Hui, Hui, IR \\ Järvinen, Miikka, 23 \\ Jo, Javier, IN \\ Joshi, Vishwas N., 20 \\ Kalita, Ranjan, 1O, 1P \\ Kassamakov, Ivan, 23
}

Katsaggelos, Aggelos, 11

Kivanc, Kose, 18

Kner, Peter, 1C

Kozorovitskiy, Yevgenia, 11

Kumar, Manish, II

Lai, Feng-Jie, $1 Q$

Lam, Edmund Y., IV

Laperrousaz, Bastien, 09

Lauderdale, James D., $1 C$

Li, Guiye, $1 \mathrm{~L}$

Li, Runze, 21

$\mathrm{Li}$, Tianmeng, IR

$\mathrm{Li}$, Yingchao, $1 \mathrm{~L}$

Liu, Ang, $1 \mathrm{~L}$

Liu, Lina, $1 \mathrm{~L}$

Liu, Yang, $1 \mathrm{C}$

$\mathrm{Ma}, \mathrm{He}, \mathrm{IR}$

Madrid Wolff, Jorge, $1 \mathrm{U}$

Martinez, Pol, 23

Martínez-Corral, Manuel, 1 A

Martinez-Rivera, Noraida, 20

Meyer, Heiko, 13

Morales, S., 09

Mullins, John J., IF

Nasenbeny, Jordan, 11

Nelson, Carl J., IF

Nolte, Lena, 13

Nolvi, Anton, 23

O'Brien, John, 20

Patwary, Nurmohammed, $1 \mathrm{~A}$

Peng, Tong, 21

Pezeshki, Ali, OE

Picollet-D'hahan, Nathalie, 09

Powell, Richard D., 20

Preza, Chrysanthe, 03, 0F, 1A, 12

Ren, Zhenbo, $1 \mathrm{~V}$

Ripken, Tammo, 13

Rosa-Molinar, Eduardo, 20

Ruan, Shuangchen, $1 \mathrm{~L}$

Saavedra, Genaro, 03, OF, 1A, 1 Z

Sahoo, Sujit Kumar, IW

Scherer, Norbert F., OR, 11

Selewa, Alan, OR

Shabani, H., 03, 1 Z

Shinogle-Decker, Heather, 20

Sie, Yong Da, $1 \mathrm{Q}$

Simpson, Garth J., 16

Sola-Pikabea, Jorge, 1 A

Sornborger, Andrew, 1C 
Stockton, Patrick A., OE

Stokoe, Robert J., OE

Tang, Dongliang, IW

Taylor, Jonathan M., 1E, IF

Tian, Jie, $1 \mathrm{R}$

Ulcickas, James R. W., 16

Vakili, Ali, 0C

VanLeuven, Ariel J., 1C

Wang, Xiaolei, OR, 11

Wilton, Rosemarie, 11

$\mathrm{XU}$, Zhimin, IV

Yang, Xin, $1 R$

Yang, Yanlong, 21

Yao, Baoli, 21

Ye, Tong, 21

Yi, Hannah, OR

Yoo, Seunghwan, 11

Yu, Xianghua, 21

Zhang, Chunmin, 21

Zickus, Vytautas, $1 \mathrm{E}$ 


\title{
Conference Committee
}

\author{
Symposium Chairs
}

James G. Fujimoto, Massachusetts Institute of Technology

(United States)

R. Rox Anderson, Wellman Center for Photomedicine, Massachusetts

General Hospital (United States) and Harvard Medical School

(United States)

Program Track Chairs

Ammasi Periasamy, University of Virginia (United States)

Daniel L. Farkas, University of Southern California (United States) and SMI (United States)

Conference Chairs

Thomas G. Brown, University of Rochester (United States)

Carol J. Cogswell, University of Colorado at Boulder (United States)

Tony Wilson, University of Oxford (United Kingdom)

Conference Program Committee

Martin Booth, University of Oxford (United Kingdom)

Charles A. DiMarzio, Northeastern University (United States)

Jonathan T.C. Liu, University of Washington (United States)

Raimund J. Ober, Texas A\&M University (United States)

Chrysanthe Preza, University of Memphis (United States)

Monika Ritsch-Marte, Innsbruck Medical Universität (Austria)

Laura Waller, University of California, Berkeley (United States)

\section{Session Chairs}

1 Structured Illumination in Multidimensional Microscopy

Thomas G. Brown, University of Rochester (United States)

2 Holography and Scatterometry

Carol J. Cogswell, University of Colorado Boulder (United States)

3 Algorithms and Imaging Theory

Carol J. Cogswell, University of Colorado Boulder (United States) 
425 Years of Multidimensional Microscopy I

Thomas G. Brown, University of Rochester (United States)

525 Years of Multidimensional Microscopy II

Laura Waller, University of California, Berkeley (United States)

6 Polarization and Light Field Microscopy

Raimund J. Ober, Texas A\&M University (United States)

7 Optical Systems for Multidimensional Microscopy

Charles A. DiMarzio, Northeastern University (United States)

8 New Methods for Particle Tracking

Monika Ritsch-Marte, Medizinische Universität Innsbruck (Austria)

9 Progress in Nonlinear Microscopy

Carol J. Cogswell, University of Colorado Boulder (United States)

10 Wavefront Coding and Point Spread Function Engineering Chrysanthe Preza, The University of Memphis (United States)

11 Multidimensional Imaging of Biological Systems

Martin J. Booth, University of Oxford (United Kingdom)

12 New Methods in Microscopy

Thomas G. Brown, University of Rochester (United States) 